\title{
Governing drug reimbursement policy in Poland: The role of the state, civil society, and the private sector
}

\author{
Piotr Ozieranski ${ }^{1} \cdot$ Lawrence Peter King $^{2}$
}

Published online: 3 November 2017

(C) The Author(s) 2017. This article is an open access publication

\begin{abstract}
This article investigates the distribution of power in Poland's drug reimbursement policy in the early 2000s. We examine competing theoretical expectations suggested by neopluralism, historical institutionalism, corporate domination, and clique theory of the post-communist state, using data from a purposive sample of 109 semistructured interviews and documentary sources. We have four concrete findings. First, we uncovered rapid growth in budgetary spending on expensive drugs for narrow groups of patients. Second, to achieve these favorable policy outcomes drug companies employed two prevalent methods of lobbying: informal persuasion of key members of local cliques and endorsements expressed by patient organizations acting as seemingly independent "third parties." Third, medical experts were co-opted by multinational drug companies because they relied on these firms for scientific and financial resources that were crucial for their professional success. Finally, there was one-way social mobility from the state to the pharmaceutical sector, not the "revolving door" pattern familiar from advanced capitalist countries, with deleterious consequences for state capacity. Overall, the data best supported a combination of corporate domination and clique theory: drug reimbursement in Poland was dominated by Western multinationals in collaboration with domestically based cliques.
\end{abstract}

Keywords Clique theory · Drug reimbursement policy · Multinational corporations · Pharmaceuticals $\cdot$ Poland $\cdot$ Post-communism

Piotr Ozieranski

p.ozieranski@bath.ac.uk

Lawrence Peter King

lpking@econs.umass.edu

1 Department of Social and Policy Sciences, University of Bath, Bath BA2 7AY, UK

2 Department of Economics, University of Massachusetts, Amherst, Crotty Hall MA 01002, USA 
Just look at how badly paid people in the Ministry of Health, the Agency for Health Technology Assessment and the National Health Fund are. If someone earns slightly more than the average pay [around \$1,000 monthly without tax] while living in Warsaw for ten or fifteen years, this shows three things. Either he is a total freak who "works for Poland," because these people have huge knowledge, or he is a loser unable to find a better place and thus is prone to manipulation, or he takes bribes... And, honestly, how many beautiful and noble madmen do we have in this country?

Member of Parliament about Polish state officials involved in the drug reimbursement process.

There has been intensive research on Poland's economy, state, and social structure conceding that the shift to capitalism has been decisive, that the state has developed unique features that mix local and Western institutions, and that activities of elites have shaped the course of post-communist transformation. ${ }^{1}$ Nevertheless, less attention has been devoted to the interplay among the state, civil society interest groups, and economic elites, including foreign investors. Studies carried out thus far have stressed, in particular, the importance of corruption and clientelistic relationships between political elites and the emerging domestic grand bourgeoisie in privatizations taking place in the early phase of transition, and then in the redistribution of "structural funds" for infrastructure development following the EU accession in 2004 (Jarosz 2001; Staniszkis 2003; Jasiecki 2013). Much less is known, however, about the methods of policy influence employed by Western multinationals which came to dominate the most lucrative, technologically advanced sectors in the Polish liberal variety of post-communist capitalism, including financial services, telecommunications and information technologies, and pharmaceuticals (King 2007; Cichosz 2001). Notably, there is a dearth of systematic studies of lobbying (e.g., Makowski 2015, p. 15), which in advanced capitalist democracies involves corporations influencing the policy process both directly, in their own name, and through seemingly independent "third parties," such as co-opted civil society groups or experts (Rampton and Stauber 2001, chapter 1). We seek to contribute to addressing these gaps in research by taking up a case study of the distribution of power in drug reimbursement, a pivotal area of Poland's health policy.

This article has six additional sections. The first presents drug reimbursement in the context of Poland's healthcare. The second sets out our theoretical framework. The third elucidates our methodology. The three subsequent sections present our results. In the concluding section, we discuss what our findings mean for understanding postcommunist policymaking.

\section{Institutional context: Poland's health and drug reimbursement policy}

Like other Eastern Bloc countries, post-communist Poland inherited a Soviet-style Semashko healthcare system characterized by strict top-down bureaucratic management, with the Ministry of Health concentrating power over spending and regulation.

\footnotetext{
${ }^{1}$ See, e.g., King and Szelényi 2005; King and Sznajder 2006; Staniszkis 1999, 2003; Higley and Lengyel 2000; Eyal et al. 1998; Wedel 1998, 2009; Ekiert and Kubik 2001; Grzymala-Busse 2007.
} 
Funded from the general budget, this system offered broad and equal entitlements to free health service (HiT 2011, pp. 16-17). However, the prolonged economic crisis of the 1980 s, followed by the "shock therapy" of the early transition, left it underfunded and underperforming across a variety of health indicators, including declining life expectancy (HiT 2011, p. 8). A major healthcare reform rolled out in 1997-2001 reinforced the principles of universal free healthcare coverage, yet within a new, Bismarck-type institutional framework. The funding of healthcare services was almost entirely transferred from the Ministry of Health to regional "sickness funds" managing mandatory healthcare insurance contributions paid jointly by employers and the workforce. In 2003, the regional sickness funds were merged into a single National Health Fund (Boulhol et al. 2012, p. 7). Within this model, the National Health Fund managed healthcare spending, signed contracts with service providers, and monitored them (HiT 2011, p. 20). At the same time, the Ministry of Health assumed the role of the regulator, setting and overseeing the implementation of healthcare standards based on, among other sources, advice provided by senior medical experts called national and regional consultants. Since 2005 another key source of expert advice has been the Agency of Health Technology Assessment (Nizankowski and Wilk 2009). Modelled on the English National Institute of Health and Care Excellence, the Agency became responsible for evaluating new medical technologies - including pharmaceuticals — using the principles of Evidence-Based Medicine.

The subsequent waves of governance reform were not matched by adequate increases of funding for infrastructure, equipment, medicines, and medical personnel salaries. Although healthcare spending grew 3.5 times in real terms between 1995 and 2009, the increase was minimal as a GDP share, and as of 2011 remained the third lowest in the EU, amounting to $7.4 \%$ (HiT 2011, pp. 55-56). Consequently, fulfilling the formal guarantees of equal access to publicaly funded healthcare was often problematic in practice, as illustrated by delays in waiting times in areas recognized as major public health problems, for example, cardiovascular diseases (Golinowska 2008, pp. 191-192). Further, the very healthcare financing model, based on work-related insurance contributions, was jeopardized by rapid population ageing and mass labor migration triggered by the EU accession (GUS 2011, p. 3; Devictor 2012).

One consequence of the constrained access to public healthcare has been widespread informal payments to physicians (European Commission 2013, p. 286), consistent with the pattern of by-passing of formal institutions of the communist "economy of shortage" before the beginning of the transition (Kornai 1980; Wedel 1986). Further, many physicians responded to growing patient demand by combining employment in the public sector with working for private clinics, and consequently being able to privatize public resources (e.g., hospital equipment) or exploit privileged institutional access (e.g., granting speedy referrals outside official waiting lists) (Sygut 2012). Insufficient funding was also associated with corruption in procurement of medical equipment (European Commission 2013, pp. 285-286).

A key policy area illustrating the implications of the new forms of governance and persistent resource constraints for relationships among key actors in Poland's healthcare is drug reimbursement. Like in other EU member states, Polish patients rarely cover the full price of prescription medicines out of pocket; instead, they usually pay nothing or a share of the price, with the rest being covered by a state subsidy (Vogler et al. 2008). Unlike the approval of new medicines, practically transferred to the EU level, drug reimbursement has been almost entirely left up to national authorities, with the 
EU setting out only generic borderline requirements for the policy process in its Transparency Directive. Given the state's power to decide which medicines it subsidizes and on what conditions (e.g., levels of patient co-payment), drug reimbursement enhances patient access to drugs deemed valuable by public authorities. This is especially important in middle-income countries like Poland, where very few people can obtain medicines through alternative channels by paying full their price (Czapiński and Panek 2007, p. 97). Further, drug reimbursement has major budgetary implications. In Poland, reimbursement spending was increasing rapidly after 1989 , reaching, in relative terms, one of the highest levels in Europe (in 2009, it constituted nearly 19\% of all healthcare expenditure) (Rada Ministrow 2010, p. 9; Golinowska 2008, p. 120). Nevertheless, like in other parts of the healthcare system, patients experienced difficulties in accessing medicines, with co-payment levels being one of the highest in the European Union (Golinowska et al. 2008, p. 120) and, consequently, pharmaceutical spending represented a "significant burden" for almost half of Polish households (HiT 2011, p. 168). Drug reimbursement is also crucial for the pharmaceutical industry (or "pharma"), because receiving state subsidies is vital for sales and recuperating costs incurred by developing new drugs. While per-capita pharmaceutical spending in Poland is still considerably lower than in its more affluent Western neighbors (OECD 2014), the country constitutes, with its population of thirty-eight million, one of the largest and fastest-growing pharmaceutical markets in Europe (Forbes 2015).

Despite its importance, social processes underpinning the development of drug reimbursement policies have attracted only a limited amount of social science research, with notable exceptions including Abraham (2009) for the United Kingdom and Vuorenkoski et al. (2003) for Finland. Scholarly interests have concentrated on other aspects of pharmaceutical policy, especially methods of influence used by the pharmaceutical industry to maximize its profits. ${ }^{2}$ Traditionally, there has been extensive research on corporate pressures surrounding the registration of new medicines with drug regulatory agencies (Abraham and Lewis 2000). A more recent body of research emphasizes drug company influence on processes such as consumerism, drug marketing, medicalization, or "pharmaceuticalisation" (Abraham 2009, 2010b; Angell 2005; Conrad 2007), diverse tactics used to influence post-registration adverse drug reaction tracking (Abraham 2002), and ideological assumptions driving policy decisions on innovative medicines (Davis and Abraham 2011b).

The next section shows how we combine insights form this context-specific literature with general theories of the state to investigate the distribution of power among key stakeholders in Poland's drug reimbursement.

\section{Theories of the state}

In the past four decades, the major theoretical contenders for a theory of the Western state have been neopluralism, historical institutionalism, and corporate domination

\footnotetext{
${ }^{2}$ Extraordinary profitability is one of the pharmaceutical industry's key distinguishing features. Over the last quarter century, it has figured almost constantly as the most profitable sector in the US economy (Angell 2005, p. xxiii), with profit margins considerably exceeding those recorded by, for example, banks, carmakers, oil and gas companies, and the media (Anderson 2014).
} 
theory. Poland, being a consolidated European democracy dominated by capitalist property relations, should be well suited for the application of these theories.

Neopluralist theory holds that public policy emerges through competition between multiple interest groups (e.g., McFarland 2004; Baumgartner et al. 2009). Although certainly influential, corporations, such as multinational drug companies, cannot dominate policy-making, because of being faced with "countervailing powers," primarily civil society organizations (Light 1995; Abraham 2009; McFarland 2004). Organizations of patients suffering from specific conditions are often provided as an example of an interest group well bestowed with non-monetary resources, including highly mobilized members and reputation (Baggott et al. 2005). Their policy role is further strengthened by expanding access to policy-making, exemplified by the United Kingdom's "patient and public involvement" model. Therefore, patient groups may be highly effective in achieving their policy goals, primarily related to expanded access to new medicines, including via building advocacy coalitions with drug companies (Deammerich 2004).

Historical institutionalists stress the key policy role of bureaucratic elites, with their interests being determined by commanding large state organizations (e.g., Finegold and Skocpol 1995; Evans 1995). In countries like Poland, with heavily underinvested health systems, these interests involve maximizing the health benefits per dollar spent and containing drug expenditure. Not surprisingly, they often clash with those of patient groups and drug companies, seeking to expand drug spending (Abraham 2007, 2009). These state interests may be effectively safeguarded through designing institutions insulating the policy process from pressure exerted by social forces and establishing well-resourced bureaucracies populated by committed career civil servants and supported by independent expert advisors (Finegold and Skocpol 1995).

Corporate domination theory argues that capitalists typically manage to neutralize the institutional frameworks of policy-making emphasized by historical institutionalists. This happens through directly placing members of corporate elites in decisionmaking positions; influencing political elites through campaign contributions and lobbying; and funding and controlling the policy-planning networks that generate authoritative experts and policy alternatives (e.g. Domhoff 2006; Domhoff and Webber 2011). More recently, corporate domination theory has emphasized "indirect methods" using the media and civil society organizations to shape public opinion and thereby influence decision makers (Domhoff 2009).

In pharmaceuticals, the corporate dominance position is perhaps best expressed by the "neoliberal corporate bias" theory, covering primarily the United States and Western Europe (Abraham 2007, 2009, 2010a Abraham and Lewis 2000; Abraham and Davis 2009). First, pharma enjoys privileged formal policy access through corporatist consultations between its sectoral representation and state bureaucracies (Abraham and Lewis 2000). Second, pharma develops close relationships with expert advisors working for regulatory agencies, with a significant effect on their recommendations on medical technologies (Abraham and Davis 2009). Third, intensive two-way social mobility between government and business-controlled organizations (the "revolving door syndrome") allows corporations to control even a well-resourced bureaucracy by populating elite positions (Abraham and Lewis 2000). Fourth, pharma turns patient groups into its "assimilated allies," so that they cannot be considered independent contributors to the policy process (Abraham 2009). 
Finally, anthropologist Janine Wedel claims that Poland's state-business relationships do not have equivalents in Western capitalist democracies. According to Wedel (1998, 2009), a "power vacuum" following the collapse of communism stimulated the emergence of elite cliques capturing strategic positions in the postcommunist state, business, journalism and academia (Wedel 1998, pp. 86-87). Being uniquely positioned at the intersection of the various sectors, cliques pursue "coincidences of interest," that is "interweave and perform overlapping roles that serve their own goals or those of their associates" (Wedel 2009, p. 1). This modus operandi contrasts with stable and clearly defined policy roles played by either civil society interest groups (neopluralism) or business-controlled organizations (corporate domination theory). Further, rather than lobbying through formal channels of access, cliques transgress state bureaucracy by "operat[ing] through personalized relationships within and across official structures" (Wedel 2009, p. 15). Clique activity also entails the privatization of state resources - primarily insider official informationvia one-way social mobility from state organizations to the private sector, which has replaced the revolving door pattern found in Western bureaucracies (Wedel 2009, pp. 17-18).

Brought in to the context of drug reimbursement in post-communist Poland, the four theories provide contrasting expectations concerning the policy outcomes.

1. Historical institutionalism would predict no or steady growth of spending on drug reimbursement, indicating successful protection of the state's budgetary interests.

2. All remaining theories would expect to see rapidly increasing budgetary expenditure, consistent with the claims on state resources made by patient organizations (neopluralism), the pharmaceutical industry (corporate domination theory) or elite cliques (clique theory).

The four theories would also posit different policy mechanisms that might account for these outcomes.

3. Historical institutionalists would envisage a drug reimbursement policy process that is well insulated from external (i.e., patient, drug company, and clique) influence via a set of limited formal consultations, with state autonomy being further protected by a stable pool of independent medical experts and bureaucrats working for state organizations.

4. Neopluralism would expect to see patient organizations as enjoying extensive access to formal consultation mechanisms and commanding sufficient resources to constitute policy contributors in their own right, and an equal partner to drug companies.

5. Corporate domination theory would expect drug companies to have unparalleled formal access to the reimbursement process and solidifying their influence via cooptation of other stakeholders, especially patient groups and medical experts, as well as the revolving door with the state organizations.

6. Clique theory would expect to see local elite cliques acting as crucial intermediaries for multinational drug companies, by-passing formal access mechanisms and lobbying informally based on personal connections acquired through one-way mobility of former state officials to the pharmaceutical sector. 


\section{Methods}

We collected our data between February 2009 and April 2010, primarily by interviewing a purposive sample of representatives of major stakeholders in drug reimbursement policy in Poland. The sample composition was determined by a review of legal documents, press coverage of reimbursement policy, and exploratory interviews (see Appendix 1 on website of author Lawrence P. King - all appendices referenced in this article can be accessed on King's website http://www.lawrenceking. net). We managed to recruit 57 out of 70 officially contacted interviewees. The nonresponse rate reflects, we believe, the reality of recruiting interviewees with busy lifestyles, often occupying top-level positions, and sometimes prone to stay out of the spotlight due to involvement in sensitive policy decisions. It is unlikely, however, that the non-responses introduced bias to our findings, as they were relatively evenly spread across all interviewee categories. To access under-represented interviewee categories, especially drug company lobbyists and state officials, we employed snowball sampling, with all 26 interview requests being successful. We conducted, as shown in Table 1, 109 interviews. We stopped interviewing when initial analysis showed that subsequent interviews generated limited new insight regarding our main research questions (Charmaz 2006, p. 113-116).

All interviewees were briefed about the broad goal of the research and gave their informed verbal consent to participate. To maximize access to their exclusive knowledge, we used a semi-structured interview format, with questions tailored to each interviewee category (Web Appendix 2, King's website). Given a long history of lobbying scandals in Polish drug reimbursement, we typically refrained from taperecording the interviews and took extensive notes instead.

We corroborated the interviews with the following documentary sources:

- 276 recommendations on drugs issued by the Agency for Health Technology Assessment

- 26 reports from the sessions of the Consultative Council at the Agency for Health Technology Assessment (http://www.aotm.gov.pl/index.php?id=357).

- The "Register of benefits" (Ministerstwo Zdrowia 2011) comprising yearly reports submitted by experts working for the Agency for Health Technology Assessment.

- Four reports issued by the Supreme Chamber of Control (NIK) (Poland's main auditing organization) on pharmaceutical policy.

- Prosecutor's investigation into a lobbying scandal related to introducing a drug for reimbursement (Prokuratura Apelacyjna 2010).

We analyzed the data with the Atlas.ti software. Like certain influential scholars working on pharmaceutical policy (Hemminki et al. 2010, p. 1172), we employed a deductive-inductive approach to coding. To examine the expectations formulated based on the theories of the state, we started with a set of general codes informed by the research questions, supplementing them by "in-vivo" codes emerging directly from the data (Charmaz 2006, pp. 55-57). The coding structure gradually took the form of code families and networks covering the main themes emerging from the data (Web Appendix 3, King's website). In presenting our data, we used "thick description" (Geertz 1973) to illustrate the mechanisms and distribution of power with the greatest amount of detail 
Table 1 Interviews with key stakeholders in drug reimbursement policy

\begin{tabular}{lll}
\hline Organization & $\begin{array}{l}\text { Number of } \\
\text { interviews }\end{array}$ & $\begin{array}{l}\text { Number of } \\
\text { interviewees }\end{array}$ \\
\hline
\end{tabular}

Ministry of Health

High Ranking officials

Middle-ranking officials

Consultants

National consultants

Regional consultants

National Health Fund

High-Ranking officials

Parliament

Seym (Lower Chamber)

Senate (Upper Chamber)

Agency for Health Technology Assessment

High-ranking officials

Innovative pharmaceutical companies

High-level managers

Lobbyists, public relations/communications officers

$\begin{array}{rr}2 & 2 \\ 15 & 8 \\ 2 & 2 \\ 3 & 3 \\ 1 & 1 \\ 1 & 1 \\ 4 & 3 \\ 3 & 2 \\ 1 & 1 \\ 4 & 3 \\ 2 & 1 \\ 2 & 1 \\ 2 & 2 \\ & \\ 2 & 2 \\ 4 & 4 \\ 1 & 1\end{array}$

Associations of innovative drug companies

Associations of generic drug companies

Chamber of commerce

American Embassy

Law firms

Lobbying firms

Freelance lobbyist

Public relations firms

Health technology assessment firm

Contract research organization

Pharmaceutical market consultancies

3

1

3

2

1

1

Patient organizations

Attention Deficit Hyperactivity Disorder

Diabetes

Oncology

Journalists

Newspapers

3

Weekly magazines

2

2

Monthly magazines

Medical doctors dealing with drug reimbursement in their professional activity

Total

possible. This involved including all voices suggesting alternative or competing explanations (Emerson 2001, p. 302). Interested readers can verify our conclusions by 
consulting Web Appendix 4, King's website, comprising additional quotes, coded around the main themes. (We refer to it throughout the article using the following code: [WA- and the number of a specific section of the Appendix]).

Although based on comprehensive analysis of interviews and documents, our case study has limitations. Most importantly, given extensive commercial and state secrecy, we did not systematically examine lobbying campaigns associated with individual drugs, the proportion of innovative medicines applying successfully for reimbursement, and price agreements reached by state officials with drug manufacturers.

\section{Drug reimbursement process}

Before analyzing the distribution of power in the reimbursement policy domain, we must outline key stages of the reimbursement process.

The Polish reimbursement system includes two major schemes: open reimbursement and therapeutic programs. The former covers primarily generics, that is, equivalents of medicines whose patents have expired, available at pharmacies with up to $50 \%$ patient co-payment. These drugs, manufactured mostly by domestic firms, tend to be relatively cheap, with relatively low profit margins (Wyżnikiewicz 2009, p. 11). The latter reimbursement scheme, therapeutic programmes, comprises "innovative," patentprotected drugs provided by hospitals, free of charge. The main type of innovative drugs offered within therapeutic programs are so-called "niche busters," 3 medicines addressed to small numbers of patients, especially those with specific types of rare diseases ${ }^{4}$ or cancer, with yearly costs sometimes exceeding $\$ 100,000$ per patient. Unlike generic drugs from open reimbursement, niche busters included in the therapeutic programs are manufactured exclusively by multinationals and commonly recognized as the future dominant business model in the sector. Given the importance of niche-buster medicines, we select therapeutic programs as the focus of our inquiry.

Like the entire healthcare governance system in Poland, the institutional framework of drug reimbursement has undergone numerous changes over the course of transition. We analyze a recent period between two legislative reforms in 2009 and 2012. New therapeutic programs were then typically initiated by "national consultants," senior clinicians overseeing distinct areas of medical or pharmacological specialization (Ustawa 2009). A consultant could request a new therapeutic program from the Ministry of Health (hereafter: Ministry) by developing a draft in collaboration with other medical experts, including "regional consultants," and drug manufacturers. The

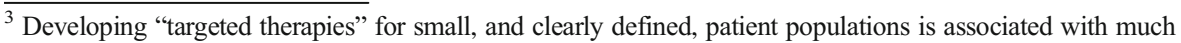
lower investment risks than in cases of medicines serving high numbers of patients. In the niche buster model, profitability stems, therefore, from a very high unit price that makes up for a low volume of sales (Dolgin 2010). However, niche busters are increasingly criticized for offering few therapeutic benefits (e.g., life expectancy gains not exceeding weeks when compared to standard therapies) and producing serious sideeffects. Furthermore, by focusing on relatively less risky areas of drug discovery, the niche-buster model may divert resources from more challenging yet vital areas, such as antibiotics or neuropsychiatrics (e.g., Lexchin 2006).

${ }^{4}$ There is no universally agreed definition of rare-or orphan-diseases. According to the European Commission (2004), "Rare diseases (...) are life-threatening or chronically debilitating diseases which are of such low prevalence that special combined efforts are needed to address them. As a guide, low prevalence is taken as prevalence of less than 5 per 10,000 in the Community."
} 
proposal had to be supported by a health technology assessment report, typically compiled by local advisory firms, covering clinical and economic aspects of proposed medicines (AHTAPol 2007, 2009).

The Ministry refined the draft submitted by the consultant and forwarded it to the Agency for Health Technology Assessment (hereafter: Agency). The Agency issued a recommendation on its suitability for reimbursement, evaluating its "health, social, economic, and ethical" aspects (AHTAPol 2012). Agency recommendations were to be informed by a position issued by the Consultative Council (hereafter: Council), comprising twelve (most often ten) senior medical experts.

The final decision about the creation of the therapeutic program was taken by the Minister of Health, based on a non-binding Agency recommendation and "social consultations" with citizens, especially patient organizations. The Minister was supposed to consider a range of Evidence-Based Medicine criteria, including public health priorities, the impact of disease on patients, clinical effectiveness and safety, costeffectiveness ratio, and budget impact.

Once established, therapeutic programs were managed by the National Health Fund, which signed contracts with hospitals providing treatments to patients and monitored their implementation.

The formal policy framework captured only part of the processes involved in the development of therapeutic programs (cf. Ozieranski et al. 2012a). To begin with, it obscured the role of pharma in triggering therapeutic programs. A high-ranking Ministry official explained:

It's true that consultants turn directly to the Minister to ... initiate therapeutic programs. The problem is that their connection to reality may be weak. That's why I prefer when an application is submitted by the drug firm. They have to prove that what they have written is true.... On the other hand, dealing with consultants is like playing Chinese whispers. It leaves a bad aftertaste. Firms shouldn't mobilize consultants to write applications for them. [WA-2,3]

Similarly, formal regulations did not reveal the importance of non-binding Agency recommendations for legitimating reimbursement decisions, allowing political elites to avoid blame for providing funding for controversial medicines. The external affairs manager at a drug company observed: "I cannot imagine a drug receiving a negative recommendation from the Agency and then included by the Minister [in reimbursement].... This would result in turmoil. That's why the Minister thinks: 'I don't want it."'[WA-4].

A key stage in the policy process, price negotiations between the Ministry and drug companies, also happened outside the scope of formal regulations (NIK 2004, pp. 2124). A partner at a law firm recounted:

There is no procedure concerning therapeutic programs, that is, those most expensive life-saving drugs.... The story goes on like this: The minister calls [the firm] saying, 'You see, you have to come here tomorrow and, you know, we'll talk.' And they have a chit-chat.... This is the type of conversation you can have over coffee. [WA-5] 
The public affairs director at a pharmaceutical company noted that informal negotiations allowed more flexibility in reaching agreements:

The Ministry of Health and the National Health Fund negotiate informally with drug companies. This allows for introducing various bonuses, such as free treatment for some patients. In the case of [open reimbursement], there is no such possibility.

Finally, decisions about the establishment of therapeutic programs resulted from a complex interplay of scientific and political factors. It would be difficult to justify reimbursing a medicine lacking any support in Evidence-Based Medicine. As the spokesperson for a drug company put it, "[T]here has to be some weight in it. If something costs a lot, to be reimbursed it needs to be supported by clinical and scientific data or a medical need or patients." Nevertheless, scientific evidence rarely provided undisputable arguments for a positive reimbursement decision, as indicated by fact that half of positive Agency recommendations lacked support in reliable medical data (Ozieranski et al. 2012b, pp. 187-188). Also, state elites faced serious challenges in creating transparent reimbursement criteria, regarding extremely expensive and often unproven drugs for small patient populations. A senior Agency official admitted:

We don't have any system for considering rare drugs [for rare diseases]. Standard quotas [e.g. thresholds of cost-effectiveness] aren't applicable here. It's not known how these applications should be processed.... [T] his problem is unsolved and it's growing.

Therefore, Ministerial decisions were often influenced by calculations regarding their likely impact on reactions by specific patient groups and the general public. A former high-ranking Ministry official remarked:

The Ministry's actions in this sphere are continually assessed by voters. Too much arrogance, too much indecisiveness, too much disrespect [for patients] can severely affect the ruling party's electoral chances and become a trigger of political change following the next general election. [WA-6, 7]

We now examine how pharma exploited the institutional design of the reimbursement process to secure favourable policy outcomes.

\section{Power struggles in Poland's drug reimbursement}

We first consider the introduction of "innovative" therapies to reimbursement. We then examine the mechanisms of lobbying instrumental in securing favourable reimbursement decisions from political elites. Next, we detail relationships between drug companies and medical experts who evaluate drugs applying for reimbursement. Finally, we explore social mobility between the state and the pharmaceutical sector. 


\section{Policy outcomes and stakeholder interests}

We analyze the distribution of power over drug reimbursement by considering spending on highly expensive niche-buster medicines. Figure 1 demonstrates that expenditure on therapeutic programs was increasing at an unsustainable pace, with the total growth reaching 534.8\% in real USD over seven years (Web Appendix 5).

The dynamics of spending on therapeutic programs was even more striking in the broader healthcare context. As evidenced in Figure 2, they were becoming a major rival to open reimbursement, the reimbursement scheme addressing large patient populations.

Additionally, Figure 3 demonstrates that the rapid growth of spending on therapeutic programs contrasted with slowly increasing expenses on long-term care and flat expenses on prophylactic programs financed by the National Health Fund.

The identified spending pattern is inconsistent with the historical institutionalist position, which would predict low or stable growth of budgetary spending. It supports, however, the expectations generated from the corporate domination, clique, and pluralist theories. First, it certainly boosted the profitability of firms pursuing the nichebuster business model. The public affairs director at a pharmaceutical company explained that "There has been great progress in the area of specialist drugs [which] ... are more numerous and ... better. Therefore, firms orient themselves towards them." In particular, clinical characteristics of niche-buster medicines provide drug companies with strong arguments for negotiations with both medical experts and political elites. The public affairs director at a drug company argued,

The type of recommendation is strongly determined by the considered drugs. If the [Agency] evaluates a therapy which is fairly effective and has no alternatives, it is very difficult to issue a negative recommendation. Even more so when it is faced with mounting pressure from patients' associations, key opinion leaders, and the media.

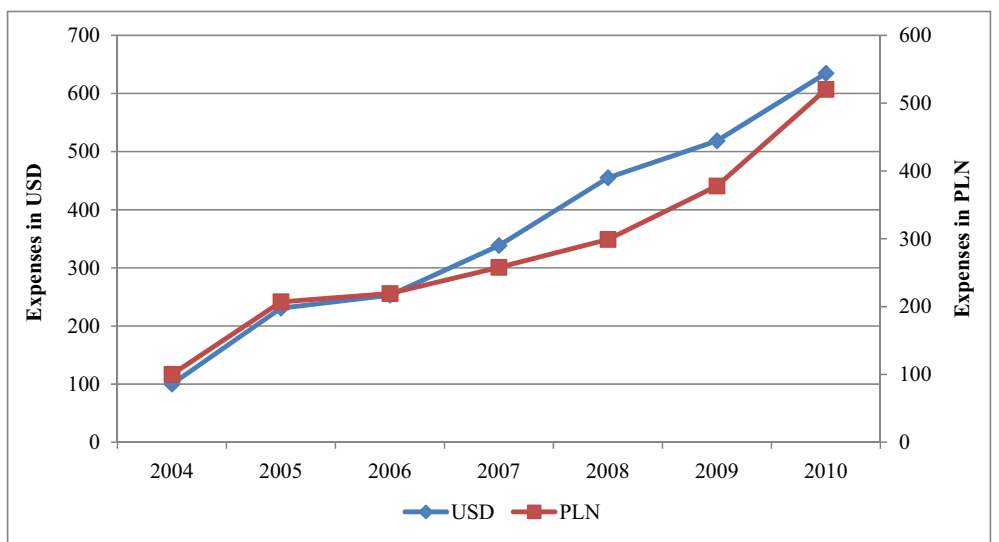

Fig. 1 Real growth of expenses on therapeutic programs (2004-2010; $2004=100)$. NOTE: Authors' calculations. Nominal expenses obtained from yearly reports issued by the National Health Fund (NFZ 2006a, pp. 20-21, 2008, p. 32, 2009, p. 32, 2011, p. 64); Inflation data obtained from the database of the Organisation for Economic Co-operation and Development (http://stats.oecd.org/Index.aspx, accessed April 22, 2011). Exchange rates between PLN and USD calculated based on data provided by the National Bank of Poland (see http://www.nbp.pl/home.aspx?c=/ascx/archa.ascx, accessed April 11, 2011) 


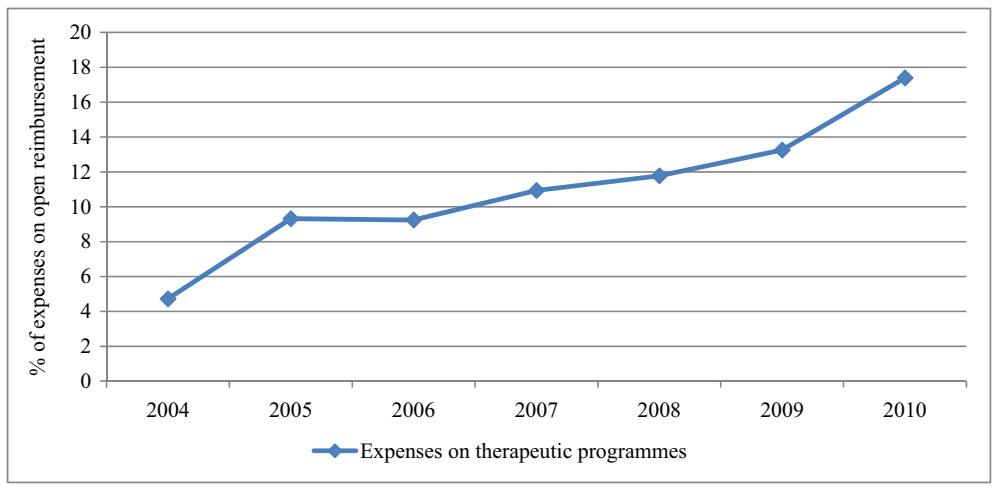

Fig. 2 Expenses on therapeutic programs as compared to open reimbursement (2004-2010). NOTE: Authors' calculations. Expenses on open reimbursement and therapeutic programs were obtained from yearly reports issued by the National Health Fund (NFZ 2005, p. 8, 2006a, pp. 20-21, 2006b, p. 15, 2008, pp. 32, 85, 2009, pp. 32, 64, 2010, p. 90, 2011, pp. 64, 99)

This account is supported by the outcomes of drug evaluation by the Agency. Figure 4 shows that between 2007 and 2011 the niche-buster strategy was consistently more effective in obtaining a positive Agency recommendation than the blockbuster strategy.

Overall, the likelihood of a receiving a positive recommendation was $74.5 \%$ for medicines applying for therapeutic programs and only $51.9 \%$ for drugs targeting open reimbursement. [WA-8].

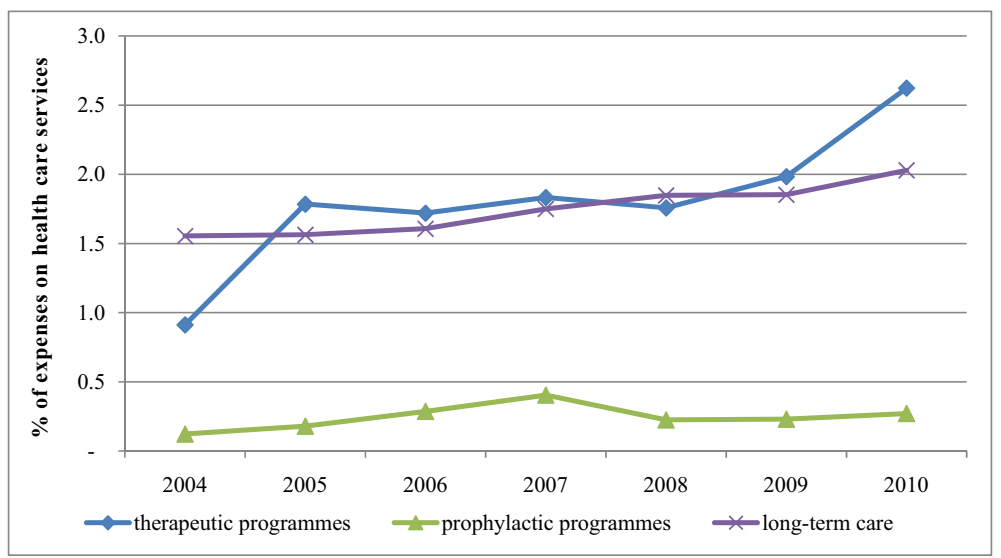

Fig. 3 Expenses on selected types of healthcare services*: therapeutic programs, ${ }^{* *}$ prophylactic programs, ${ }^{* * *}$ and long-term care ${ }^{* * * * *}$ financed by the National Health Fund (2004-2010). NOTE: Authors' calculations. Expenses on healthcare services, therapeutic programmes, prophylactic programmes and long-term care were obtained from yearly reports issued by the National Health Fund (NFZ 2005, pp. 28, 37, NFZ 2006a, pp. 20 $22,29,2007$, pp. $28,32,114,2008$, p. 32,2009 , pp. $32,37,134,2010$, p. $76,177,2011$, pp. $64,87,180)$. "As of 2011, expenses on healthcare services constituted 95.5\% expenses of the National Health Fund, covering 19 types of expenses, including drug reimbursement, prophylactic programmes and long-term care. ** Therapeutic programmes comprise expensive drug therapies (usually niche busters) for narrow patient populations. ${ }^{* * * *}$ Examples of prophylactic programmes include: prophylaxis of cervical cancer, breast cancer, prenatal testing, smoking-induced diseases, cardiovascular diseases and tuberculosis (NFZ 2011, pp. 86-87). ${ }^{* * * * *}$ Long-term care includes both care provided patients with long-term conditions who do not require hospital care and palliative and hospice care (NFZ 2010: 67) 


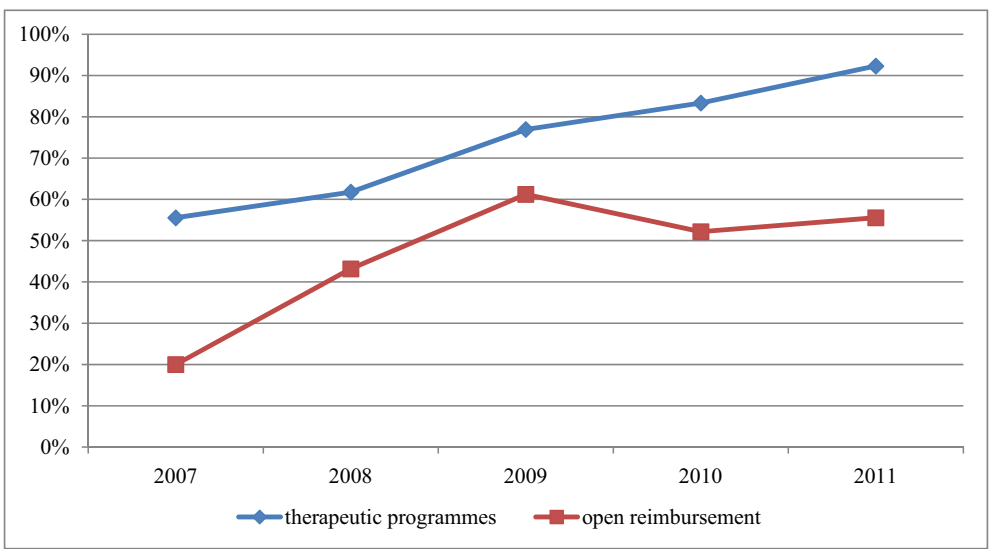

Fig. 4 Positive recommendations concerning therapeutic programs and open reimbursement issued by the Agency for Health Technology Assessment. NOTE: Authors' calculations based on recommendations obtained from the website of the Agency for Health Technology Assessment (http://aotm.gov.pl/index. $\mathrm{php}$ ?id=12). The numbers of positive recommendations regarding therapeutic programmes (hospital therapies for narrow groups of patients) were 5, 21, 20, 10 and 24 in the subsequent years. As far as open reimbursement (pharmacy drugs for large patient populations) is concerned, the respective figures were 1, 19, 30,24 and 10. The total count of recommendations includes two recommendations from 2008 in which no position was taken

Second, the uncovered spending pattern was also consistent with the interest of elite cliques, with members occupying key positions at the Ministry, in using spending on "newsworthy diseases" to boost their popularity among voters. For example, according to an ex-Ministry official, "Orphan diseases are a different matter. Even if there are only four or five patients and the treatment is very expensive, there's still much to show off [in the media]." [WA-9, 10].

Finally, creating therapeutic programs met the demands of patient organizations from some condition areas. Nevertheless, this should not obscure fundamental differences between the interests of patients and the pharmaceutical industry, especially around drug safety (Abraham 2007), as well as opportunity costs and inequalities in healthcare access generated by prioritizing extremely expensive drugs for selected conditions. [WA-11, 12, 13].

We now analyze the social processes that - in the light of our interviewsunderpinned the increasing spending on innovative drugs.

\section{Lobbying for drug reimbursement}

Contrary to what corporate domination theory would expect, drug companies' formal access to the reimbursement process was constrained by long waiting periods and a narrow set of topics covered in official consultations. As the external affairs manager at a drug company summarized, "These possibilities to cater for a reimbursement application are extremely limited." Taken on the face value, these observations would be consistent with the historical institutionalist position, envisaging constrained policy access for non-state actors, including corporations. Nevertheless, in fact, the procedure of restricted consultations involved a "ritualistic" use of formal institutions (Wedel 1998, p. 90), which allowed political elites to create the impression that they took a 
tough stance on profit-greedy multinationals. A director at a pharmaceutical market consultancy commented on formal meetings with drug companies:

[Q]uite simply, after the scandal with X [a high-ranking Ministry of Health official involved in irregularities in introducing a drug to reimbursement] ... they [Ministry officials] are afraid that they will lose their posts and ... will be grilled by the media.... A regulation [has been introduced] that they must meet in pairs or trios with people from the outside [i.e., representatives of the pharmaceutical sector]. So, it is totally trendy because they want to have peace and quiet. Because, you see, since they implemented this regulation there has been no scandal regarding drugs at the Ministry.... OK, they have buried the problem because there are no discussions [with the pharmaceutical industry].

However, pharma managed to bypass the rigid formal consultations. A Vice-Minister of Health admitted during a parliamentary hearing: "The lobbing legislation [which regulates drug companies' formal access to Ministry] functions poorly.... [T]o say that those firms don't lobby [apart from the formal meetings] would be a blatant lie, because they do so" (Piecha 2006).

Overall, we identified no evidence of effective insulation of the policy process, which would fall in line with historical institutionalism. Nor did we find evidence of privileged formal policy access enjoyed by drug companies, predicted by corporate domination theory. Our data did show, however, extensive informal openness of the policy process consistent with clique theory. [WA-14, 15, 16].

We now explore two primary lobbying methods revealed by our data-informal persuasion and third party endorsements, which correspond with the pattern of formal closedness and informal openness of the policy process.

\section{Informal persuasion via cliques}

Many pharmaceutical lobbyists and even some state officials viewed informal persuasion as a key lobbying method. A former high-ranking Ministry official noted: "If extreme wealth is at stake, informal methods must play a vital role." Pursuing informal lobbying was premised on personal relationships with officials at the Ministry, the National Health Fund, and the Agency. A representative of an association of pharmaceutical companies stressed these ties could be decisive in determining the fate of drugs applying for reimbursement. "Some firms are successful [in securing access to the Ministry leadership]. This is based on contacts. Contacts among colleagues and friends are crucial.'’[WA-17, 18].

The importance of informal lobbying was rooted in the composition of the social milieu involved in shaping reimbursement policy, comprising several tightly-knit "social circles" or cliques (Wedel 1998). "The group of people engaged in reimbursement is very small," admitted a representative of an association of pharmaceutical companies, with its members sharing educational and career backgrounds. As an employee of a lobbying firm emphasized, "Only medical education allows for speaking with decision-makers who are doctors themselves." Importantly, this group operated flexibly at the intersection of the public, private, and third sectors (Wedel 2009). For 
instance, some high-ranking state officials were lecturers in reimbursement policy for a Master of Business Administration course. According to an Agency official,

[T] his is corruption in velvet gloves. Who can afford to pay such fees for a course [around \$10,000]? Only for drug companies this is no money whatsoever. So, this is a loophole for drug companies. In this way, they don't have to pay the decisionmakers directly.

Furthermore, social relationships within the social circles were durable and involved multiple social roles and ties (Wedel 1998, chapter 3). As an ex-high-ranking Ministry official described:

Ministers, decision-makers, doctors - they all came from the same context. They all had contacts with [drug companies'] reps [medical representatives]. Then the reps were promoted in their firms and started visiting 'their' doctors who became ministers.

Finally, the reimbursement policy domain formed "a closed circuit", a journalist noted. The communications manager at a drug company recounted, "Just look at my career path. I initially worked for [firm] X, then for Y, later for Z.... But ... I have been meeting the same people all the time."

A key consequence of the policy involvement of informal social circles was blurring the state-private divide (Wedel 2009), perhaps best illustrated by the development of public health technology assessment guidelines used by the Agency to evaluate drugs applying for state reimbursement. Despite formally representing different stakeholders, experts creating the guidelines constituted one social circle. The external affairs manager at a pharmaceutical firm commented:

All prestigious health technology assessment companies [developing reports that support drugs applying for reimbursement] ... and the Agency [evaluating the reports] originate from the same community. These are several dozen people who know each other very well. They have functioned in this small milieu for many years, studied together, formed a pressure group. Their paths have diverged with time but their work overlaps.

Being part of the expert group generated "coincidences of interest" (Wedel 2009, p. 12), at least for some representatives of health technology assessment companies operating based on the public guidelines. The public affairs director at a pharmaceutical company noted:

[Some of] [t]hose advisory firms utilize in a mercantile way their contacts and position in the system.... For me, this is a classic conflict of interest-it's difficult to advise public institutions [i.e., the Agency] when being part of the process [i.e., developing commercial health technology assessment reports]. Increasingly, this unregulated intersection is becoming a major potential problem. [WA-19]

There were many forms of informal persuasion, all characterized by a low risk of "catching anyone red-handed," according to a Ministry official. The cliquishness of the 
reimbursement policy domain was therefore instrumental in maintaining "deniability" (Wedel 2009) or "institutionalized unaccountability" (Hausner and Marody 2000) of both state and non-state actors involved in policy-making. For example, prosecutor's investigation of irregularities associated with introducing drug A to reimbursement illustrates "food, flattery and friendship", a method of generating extended reciprocity often observed in pharmaceutical policy in the United States (Angell 2005, p. 142).

$\mathrm{X}$ [high-ranking Ministry official] and Y [drug company's representative] had close informal contacts. [They] met on numerous occasions both at the Ministry and restaurants as well as hotels.... the majority of bills for the meetings were paid by Y.... This ... suggested that it would have been highly likely that Y, ... using close contact with $\mathrm{X}$, could have informally influenced $[\mathrm{X}]$ to introduce [drug A to reimbursement]. However, there is no evidence that these pressures occurred.... $\mathrm{X}$ 's conduct related to maintaining intimate contacts with the representative of a drug company must nonetheless be considered improper (Prokuratura Apelacyjna 2010, pp. 145-147).

A contrasting form of informal persuasion was "kompromat" (Ledeneva 2006, chapter 3). According to a high-ranking Ministry official, it was possible to

Imagine that a doctor attends [medical] congresses which a drug company sponsors for him, together with their 'intimate side'. And they use this opportunity to take some pictures of him with this girl. Then when this man becomes, say, a 'Vice' [Vice-Minister], they've got him in their hands. This dirt is extremely powerful. [WA-20, 21, 22].

Overall, both the selective informal openness of the reimbursement process and the corresponding evidence of informal lobbying supported the expectations generated from Wedel's clique theory.

Despite their clear preference for informal lobbying, not all drug companies had sufficiently strong personal connections to pursue it. As a manager at a HTA firm observed, only "Those who do not have impeded contacts meet leisurely in the evening with ministerial advisors and [Ministry] officials." We focus below on the policy involvement of patient organizations to ascertain whether our data were more consistent with the neopluralist position (independent patient group lobbying) or the corporate domination theory (patient groups co-opted and used as lobbying instruments by pharma).

\section{Third party techniques}

In line with neopluralism, patient organizations enjoyed broad formal access to the reimbursement process: they participated in "social consultations" organized by the Ministry, submitted opinions and, unlike drug companies, gave testimonies before the Agency. Furthermore, patient organizations sought to influence the Ministry through protests and appearing in the media (Baggott et al. 2005, chapter 11). [WA-23].

In doing so, patients organizations commonly collaborated with pharma, given the shared interest in the speedy reimbursement of innovative drugs. [WA-24]. However, 
contrary to neopluralism, our interview evidence strongly suggested that these were not coalitions formed by equal partners. While the interviewed pharma's representatives commonly stressed that their relationships with patient organizations were altruistic, they were often rather critical of their competitors. The president of the local branch of a multinational drug firm argued:

Often, campaigns are forced and used to exert pressure on drug policy. Cooperation with patients is very intensive when products are not reimbursed. But what happens after the product becomes available [in reimbursement]? Then a question can be asked if this was a real public campaign or rather a way to influence drug policy.

In particular, some drug companies created organizations tailored to lobbying campaigns linked to specific medicines (Healey 2004, pp. 225-226). A journalist elucidated:

A drug company has a new drug for a certain condition, yet it is not reimbursed.... The firm initiates the establishment of the association, since it has long-term contacts with doctors, key opinion leaders [in the medical milieu], and through them it accesses patients dispersed around the country. It also facilitates networking among patients from various places.... Then, patients associate and we have a new organization.

The association was subsequently involved in "actions favorable for this company," as a former high-ranking Ministry official explained. For example, they "organize press conferences saying that there is a specific drug they would like to have reimbursed." However, this is not to say these "assimilated allies" of pharma (Abraham 2009; Davis and Abraham 2011a) are devoid of motivated members. A director at a public relations company stressed: "The key thing is to have authentically involved people.... No communicational actor can control, mobilize patients, make them look credible."

Establishing the "patient-industry complex" was clearly consistent with the corporate domination theory, and it involved methods of cooptation familiar from Western countries like the United Kingdom and the United States (Davis and Abraham 2010).

Some patient organizations were controlled through money transfers (cf. Abraham 2009, p. 959), the situation exacerbated by the dearth of state grants. A high-ranking Ministry official noted,

[I]f drug company X pays hundreds of thousands of euro, for instance, yearly, then they say plainly: 'We finance your jobs and trips and it must be your role to explain that our drugs are the best.'

The financial dependence on drug companies is increased due to the dearth of available state grants. According to a national consultant,

In Poland, the institution of patients' associations is turned upside down.... It is not like in the [United] States, where associations acquire money in various ways. Here, it is only a stream of money from one or another drug company. 
Another method of control entailed the provision of manipulated medical information (Health Committee 2005, pp. 75-76). A Member of Parliament stated:

Parents are told that this medicine is super effective and will greatly improve their children's state of health. Though all the signs are that this is not true. And those people, clinging to this fresh hope, contact each other and develop the organization.

Furthermore, pharma orchestrated the lobbying activities of some patient organizations. As a key account manager at a pharmaceutical firm recounted,

In Poland, patients' associations lobby only when given impetus by the firms. They are simply unable to act on their own and need to be wound up like a mechanical toy. We need to tell them what to do, write letters or organize press conferences for them.

Not surprisingly, representatives of patient organizations were irritated by such allegations. The president of an association of patients suffering from diabetes argued:

Many journalists ... piss me off so much on so many occasions! For example, [they claim] we defend [drug] companies so much, because they keep me on a string. And I say that I'm kept on their insulin, not their string, and that's a fundamental difference.

Nevertheless, control over lobbying activities sometimes took subtle forms like the provision of lobbying know-how. Referring to the interviewee quoted above, the president of a domestic lobbying firm acknowledged that he had "conducted media training for him, which was ordered by a drug firm."

A final method of control involved providing patient organizations with "charitable" donations of expensive niche-buster medicines applying for reimbursement. As a director at a domestic public relations firm described,

They [a drug firm] were giving away drugs apparently as a form of humanitarian aid. Patients got used to the drugs, which were unique in their kind. If the drug is taken away, you can expect loads of letters to the Ministry demanding its immediate introduction to reimbursement. [WA-25]

State officials often suspected that patient organizations were mobilized by drug companies (cf. Davis and Abraham 2010, p. 12). A high-ranking Ministry official argued: "The industry is always behind patients' associations. Maybe not always but in the vast majority of instances." Nonetheless, the effectiveness of patient organizations as a third party was still high given their impact on how political elites were portrayed by the media. The president of a pharmaceutical firm noted:

Politics is strongly shaped by public perceptions. A politician is always a politician in the first place and only then he is an expert. Obviously, the Minister 
would like to be photographed with serious experts and happy patients ... [and] would prefer to avoid a smear campaign where patients accuse him of being denied access to drugs. [WA-26]

Therefore, drug companies were uniquely positioned to offer elites attractive "creditclaiming opportunities" (Hood 2011, p. 71). According to a representative of an association of pharmaceutical companies,

When we find the right moment, the decision maker views our help as a blessing. For instance, we give him the drug and he can present himself as the savior. Or we can rescue him politically. Or show that the solution we propose will not be that costly.

Overall, the evidence of pharma's close control over patient organizations and their effectiveness as a lobbying tool was more consistent with the corporate domination position than with neopluralism.

To summarize the discussion of the lobbying methods, our data confirm the expectations of both clique theory (informal lobbying via cliques) and the corporate domination theory (lobbying via patient organizations acting as "third parties").

Even so, despite the evidence of powerful lobbying methods directed at state officials, historical institutionalists might still argue that the institutional set-up of the reimbursement process could limit clique or corporate control. Specifically, the near necessity of receiving a positive recommendation from the Agency for Health Technology Assessment could be a source of independent expertise supporting state autonomy in the reimbursement process. We now discuss whether this was the case.

\section{Capturing medical experts}

We examine the extent of independence of medical experts from pharma by focusing on the Consultative Council, the key expert body within the Agency for Health Technology Assessment, given its role in legitimizing reimbursement decisions taken by political elites. We analyze the breadth, nature, and consequences of relationships between the experts and the industry, without, however, making any claims about individual Council members.

The Ministerial "Register of benefits" (Ministerstwo Zdrowia 2011) reveals that nine out of ten Council members reported conflicts of interest between 2009 and 2011, a proportion significantly higher than in other European drug regulatory agencies. ${ }^{5}$ Table 2 demonstrates three clusters of Council members, displaying high, medium, and low levels of relationships with pharma. A high-ranking Agency official commented on this pattern:

\footnotetext{
${ }^{5}$ Relationships with the pharmaceutical industry were reported by $26 \%$ of senior management of the Irish Medicines Board; $28 \%$ of members of the Executive Board of the Medicines and Healthcare Products Regulatory Agency in the United Kingdom; and 25\% of members of the Management Board of the European Medicines Agency EMA (Lexchin and O'Donovan 2010, p. 645; cf. Abraham and Lewis 2000, pp. 58-59). This comparison should be treated with caution due to differences in the roles of these bodies, their size and approaches to defining conflict of interests, as well as the period of time under observation.
} 
Table 2 Conflicts of interests reported by Consultative Council members (2007-2008)*

\begin{tabular}{lc}
\hline Consultative Council members $^{* *}$ & Number of conflicts of interests (\%) \\
\hline A & $41(36.6 \%)$ \\
B & $42(28.6 \%)$ \\
C & $19(17.0 \%)$ \\
D & $6(5.4 \%)$ \\
E & $4(3.6 \%)$ \\
F & $4(3.6 \%)$ \\
G & $2(1.8 \%)$ \\
H & $1(0.9 \%)$ \\
I & $1(0.9 \%)$ \\
J & $1(0.9 \%)$ \\
K & $1(0.9 \%)$ \\
Total & $112(100 \%)$ \\
\hline
\end{tabular}

Authors' calculations. Aggregated based on reports from Consultative Council sessions available on http://aotm.gov.pl/index.php?id=11

* - conflicts of interest reported in relation to 83 drug-related "decisional problems" considered the Consultative Council

** - Consultative Council members' names are anonymized

A geneticist or a philosopher doesn't prescribe drugs.... That's why from the perspective of drug companies those are not the types of people worth investing in. On the other hand, in the Council you also have an endocrinologist or oncologist. They are constantly under pressure, particularly if they are first class clinicians who prescribe very expensive drugs.

The fact that nearly every Council member had relationships with pharma and some of these were very close lent support with the corporate domination position, envisaging a high level of cooptation of medical experts by pharma. [WA-27].

We further examine the nature of relationships between the two sides by delving into specific types of conflicts of interests reported by Consultative Council members. The interview data are instrumental in understanding the significance of these ties for the medical experts (see Table 3).

First, relationships with pharma guaranteed experts' access to cutting-edge medical knowledge through sponsored medical congresses (cf. Fishman 2004, pp. 195-196; Lakoff 2004, p. 263) and provision of research materials (cf. Abraham 2010a, p. 648; Healey 2004). This assistance was particularly important, because, as a regional consultant observed,

[A] Polish hospital usually doesn't have money for salaries or energy, and subscribing to scientific journals, buying books or ... online access to medical data bases [is impossible]. I don't know a hospital director who would do such things, since there's simply no money for this. 
Table 3 Types of conflicts of interests reported by Consultative Council members (2007-2008)*

\begin{tabular}{lc}
\hline Types of conflicts of interest $^{* *}$ & Number of conflicts of interest (\%) \\
\hline Delivering lectures, workshops, scientific sessions & $71(63.4 \%)$ \\
Investigator in clinical trials & $13(11.6)$ \\
Membership in advisory bodies & $12(10.7 \%)$ \\
Unspecified research & $7(6.3 \%)$ \\
Participation in congresses and conferences & $5(4.5 \%)$ \\
Preparing analyses, reports, publications & $4(3.6 \%)$ \\
Relationships with third parties close to a Consultative Council member & $3(2.7 \%)$ \\
Receiving drug samples & $2(1.8 \%)$ \\
Working as an expert & $1(0.9 \%)$ \\
Unspecified contract & $1(0.9 \%)$ \\
Attempt of contact by a drug firm & $1(0.9 \%)$ \\
Total & $112(100 \%)$ \\
\hline
\end{tabular}

NOTE: Authors' calculations. Aggregated based on reports from Consultative Council sessions available on http://aotm.gov.pl/index.php?id=11

* - conflicts of interest reported in relation to 83 drug-related "decisional problems" considered the Consultative Council

** - The categorisation of conflicts of interest is inductive

An audit conducted by the Supreme Chamber of Control in a large hospital offers a quantitative illustration of the extent to which doctors' research activities are supported by pharma (NIK 2007, p. 2; a similar pattern was identified in numerous other audited hospitals, e.g., NIK 2010a, 2010b):

During the period covered by the control, financial donations made by drug companies constituted $67.6 \%$ of all financial donations made to the hospital and [the companies] were among the most active in financing or co-financing foreign trips to symposiums and conferences.

Importantly, another report highlighted that in 8 out of 13 audited major hospitals the sponsorship of conference trips, seminars and training was unregulated and not monitored (NIK 2010a, pp. 54-57) [WA-28].

Second, pharma provided medical experts with financial incentives well described in Western countries (Angell 2005). For example, some medical experts attended sponsored professional meetings in high-end tourist destinations (Ministerstwo Zdrowia 2011). As a high-ranking Ministry official commented,

Trips to exotic places still take place. In Poland, there are no strict rules in this area.... It is only said that a conference should be organized decently but without lavishness, and it should not exceed the norms of hospitality.

Nevertheless, the most important mechanism was-like in the West (Angell 2005; Fishman 2004; Healey 2004) — the clinical trial. Audits conducted by the Supreme 
Chamber of Control demonstrate that in the absence of coherent oversight clinical trials constituted a system of exchange of favors between some senior doctors and pharma (NIK 2007, 2010a, 2010b). A high-ranking National Health Fund official charted:

Sometimes clinical trials are a legalized form of corruption. Firms pay vast amounts of money to a certain professor officially for being the principal investigator.... However, in reality he's paid for promoting the drug among other experts, decision-makers and patients. This form of hidden financing is safer for a drug company. To pay for consulting or lectures, they need to prepare a contract and staggering sums would certainly look suspicious there. On the other hand, paying horrendously high fees for clinical trials doesn't surprise anyone.

Similarly, audits conducted by the Supreme Chamber of Control in a number of hospitals demonstrated that clinical trials underpinned a system of exchange of favors between some drug companies and parts of the medical establishment (NIK 2007, 2010a, 2010b).

Another form of developing financial relationships with medical experts, extensively researched in the United States, was continuing medical education (Angell 2005, pp. 138-141; Fishman 2004). In Poland, this mechanism offered considerable opportunities for informal money transfers. As a national consultant noted,

It is obvious that for a lecture sponsored by a drug company I receive a negotiated fee.... Yet it happened to me several times that I had a lecture for another firm or even a non-sponsored lecture ... where I was called and told: 'Look, if you said this about this and that, we would pay you an additional fee.' [WA-29]

Finally, the research and financial incentives offered by pharma reaffirmed experts' recognition in the medical milieu (cf. Lakoff 2004, p. 263). This was illustrated by a high-ranking Agency official's comment on large research grants offered by drug companies.

This money does not end up in an expert's pocket.... He will spend it on his clinic, his people, $\mathrm{PhD}$ students, research; in short, on building his own position in science. He will not spend it on extravagances, dissipation, a trip around the world five times. No, he will spend it on establishing his position in science because this is the thing he values most. For me, this is corruption. [WA-30, 31]

The impact of these lucrative forms of support was reinforced by pharma's selectivity in choosing their recipients (NIK 2010a, p. 56). A spokesperson for a drug company emphasized: "If there's a 'number one event' every doctor would like to be there. But not everyone can afford it.... A firm's budget is not made out of rubber. We can send two, three, five people to a cardiology congress." However, unlike patient organizations, medical experts could diversify cooperation with firms from their speciality areas (cf. Lakoff 2004, pp. 262-263).). A key account manager at a drug 
company noted: "Firms obviously compete for ... attention" of a small number of opinion leaders. In addition, the public affairs director at a pharmaceutical firm asserted: "Exclusive cooperation with just one firm happens, but only occasionally. We do not want to cooperate with such KOLs because they are too strongly oriented towards that firm." [WA-32, 33].

On the whole, the fundamental importance of relationships with pharma for medical experts' professional position was consistent with corporate domination theory. However, the evidence of informal interactions associated with conflicts of interests, such as congresses, clinical trials and paid lectures, also gave support to the clique theory, emphasising informal relationships between members of elite cliques, in this case drug company representatives and members of the medical establishment. ${ }^{6}$

While the experts interviewed saw themselves as impartial, they admitted that receiving pharma's support could bias scientific judgement. A national consultant explained:

Obviously, firms have the opportunity to influence [experts], because if you're preparing a lecture and ask them for scientific materials, they will be very happy to send you ... loads of articles describing very positive events. And it can even be done objectively. But in this way you can expect to have a hundred concerning the positives. But a hundred of negatives you have to find on your own, if you can be bothered. If you can, you arrive at an objective picture. But if you can't and choose the easy way....

Furthermore, conflicts of interest sometimes created privileged access to expert advisors, which was particularly important given the constraints existing in the formal consultations between state officials and drug companies. According to a partner at a law firm, "Firms have access to Council members. Those professors have cooperated, they give lectures. They have had relationships with firms." Therefore, the expert's structural dependence on pharma entailed the risk of creating generalized reciprocity (cf. Lakoff 2004, pp. 255-256), making the experts more likely to "take a collaborative, rather than adversarial approach to pharmaceutical firms" in the long run (Abraham and Davis 2009, pp. 590-591). One medical expert noted:

The mechanism of exchanging services and favours operates ad infinitum. These are delayed services. This works like as pointed out in the Godfather: "One day I will come to you and ask you a favor. And then you'll repay me for everything."

This account clearly resembled the "pharmaceutical gift cycle" model, highlighting the importance of dependency networks with doctors for pharma's market expansion in both the United States and global peripheries (Oldani, 2002; Lakoff 2004: 255-256). In the resource-poor post-communist context, the risk of biasing scientific judgement was associated not only with positive incentives offered by drug companies but, perhaps

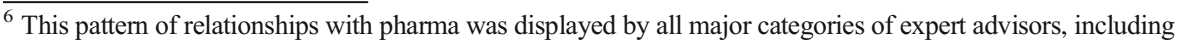
national consultants, involved in developing therapeutic programmes. The "Register of benefits" (Ministerstwo Zdrowia 2011) shows that 19 out of 31 (61.3\%) national consultants and their regional aides invited to Council sessions reported the same types of conflicts of interest as the Council members. These results should nonetheless be approached with a degree of scepticism due to frequent inaccuracies in consultants' reports and a high extent of nondisclosure.
} 
even more importantly, the anticipated devastating impact of the withdrawal of drug companies' support for experts' careers (cf. Abraham 2009, p. 961; Healey 2004). An Agency official admitted: "Sometimes it's very difficult to differentiate between incentives and pressure." [WA-34].

Without sufficient documentary data we could not compare the voting patterns of Council members with and without conflicts of interest. Nevertheless, the limited transparency of the policy process should itself be viewed as indicating bias towards corporate interests (Abraham and Davis 2009).

Even so, historical institutionalists might still maintain that pharma's control over medical experts was constrained by the formal regulations requiring Council members to report conflicts of interest, which might be followed by exclusion from voting or discussion when taking recommendations on specific drugs (AHTAPol 2011). However, like in Western regulatory agencies reports from Council session highlighted a tension between attempts to control the impact of conflicts of interest and the need to use Council members' expertise (cf. Abraham 2010a, p. 649; Abraham and Lewis 2000 , p. 59). While experts with conflicts of interest were never excluded from discussion, they were excluded from voting in 45 out of $81(55.6 \%)$ instances when reporting one or more conflicts of interest. According to an Agency official,

If they stuck to this merciless, ruthless rule [exclusion from discussion or voting], especially when there are only five people present, they wouldn't be able to take a decision. [Even so,] these are indeed muddled compromises. I'm fully aware that it shouldn't be like this.

Lastly, the monitoring of declarations of conflicts of interest was trust-based, without scrutiny by the Agency or an external body. According to a manager at a health technology assessment firm,

And what if a declaration [of conflicts of interest] doesn't reveal the truth? What's decisive is good relations with the Minister of Health. The Minister knows who should be trusted: Those who share common interests with him. [WA-35]

Overall, the structural dependence of medical experts coupled, with evidence of the "permissive principle" (Abraham and Davis 2009) in managing their conflicts of interest, enabled drug companies to largely neutralize a key source of expert capacity, contrary to the historical institutionalist position.

While the data have thus far been consistent with both the clique theory and corporate domination theory, we must yet examine the independence of the state bureaucracy, the ultimate source of state autonomy, according to historical institutionalists. To this end, we concentrate on the career paths of officials working for state organizations involved in the reimbursement process.

\section{The "Fire Exit" Syndrome}

Contrary to historical institutionalism, predicting the existence of a stable pool of career bureaucrats, we found intensive mobility from all state organizations to the 
pharmaceutical sector. For example, only six out of 17 officials involved in developing the health technology assessment guidelines, described earlier in this article, remained in state organizations (as of mid-2011). Those who left joined local health technology assessment firms (six), multinational drug companies (positions commonly associated with lobbying) as well as their sectoral association (three), a pharmaceutical consultancy (one), and academia (one) (Niżankowski and Wilk 2009; AHTAPol 2007, 2009). On top of the high-level transfers, the most intensive mobility involved the middle level of organizational hierarchy. According to a freelance lobbyist, "After two years they move to a pharmaceutical company. This is the present career model." By contrast, transfers from the pharmaceutical sector to state organizations were very rare. A journalist stressed: "Note that cadres flow only from the Ministry to drug companies and there's no movement in the reverse direction." The prevalence of one-way mobility from state organizations was consistent with Wedel's clique theory, not the corporate domination theory, which would expect to see a "revolving door" pattern. [WA-36].

This "fire exit" syndrome was mainly triggered by low wages in the state organizations, contrasting with attractive career opportunities offered by drug companies. A high-ranking official recalled:

A powerful pharmaceutical firm tried to hire me.... They ... offered [me] a managerial post related to dealing with the company's external stakeholders.... They were obviously trying to win me over using the argument of high earnings ... people having similar posts to mine had also been cornered in this way. They were offered a monthly payment somewhere in the region of $\$ 10,000 \ldots$. However, if I had small children, the desire to have a large house and a new car, I would've broken down.

A high-ranking National Health Fund official noted that the disparity in earnings between state organizations and the pharmaceutical sector "is a structural problem. The cap on earnings in public offices is subject to top-down regulations for the whole state sector." [WA-37].

Also consistent with the clique theory, the outflow of highly trained bureaucrats and experts entailed the privatization of vital elements of bureaucratic capacity, especially long-term organizational memory. A high-ranking Agency official admitted: "I deeply regret that X [a Consultative Council member] has left us. He was ideally informed about drug prices and sales.... None of us had this sort of information." Also, increasingly mobile bureaucrats and experts sometimes adopted a friendly attitude towards drug companies, a phenomenon highlighted by both clique and corporate domination theories (Abraham and Davis 2009, p. 590). A Member of Parliament stated boldly: "Those people are very vulnerable to various pressures because they want to find a good job afterwards." A middleranking Ministry official described the extended reciprocity mechanism underpinning mobility to the pharmaceutical sector:

Only an idiot would accept money. We should look at the broader context.... There are more subtle methods of influence than paying people. What counts for them is not only the present, but also the future.

Unlike in historical institutionalism, we observed, therefore, self-perpetuating erosion of state capacity. The resulting bureaucracy moved away from the "rational" 
model, stressing meritocratic recruitment, long-term rewarding career prospects, and norms of neutrality and disinterestedness (Bourdieu 1994). [WA-38].

As the clique theory would expect, the "fire exit" mobility pattern boosted pharma's power through privatized informational capital concerning the highly secretive reimbursement process. An experienced external affairs manager at a drug company admitted:

Ex-officials know how to move smoothly within the Ministry, whom they should talk to or address a letter to. Though I try very hard, I don't know this, because I didn't work there.

Insider expertise was reinforced by personal relationships, important in direct interactions with state officials. A freelance lobbyist recounted:

We have someone there with whom we used to sit at the same desk and drink tea. And this person says that our application is ok, and theirs [another company's] will not pass, since it is 'incorrect.'

The number of personal connections accumulated by bureaucrats-turned-lobbyists was therefore a key determinant of their firms' market success. As the communications manager at a drug company emphasized, "Some [lobbyists] have greater capabilities than others. If a firm lacks them, it translates into limited access.... [This] can obviously affect the drug's chances of being reimbursed." Crucially for drug companies, both expertise and informal connections could be drawn not only from top but also middleranking officials, who privatized fragments of the reimbursement process, which resembled the pattern of informal appropriation of state power under communism (Podgórecki 1994, p. 50). As a freelance lobbyist expounded,

A firm is reasoning this way: 'Let's employ someone who knows other people from the Ministry. Though he is only a pawn, he has certain insider information which may be useful in bringing some things closer, speeding [things] up, getting knowledge about the competition.' [WA-39]

Overall, unlike in the "revolving door" pattern, drug companies' power was not increased through bringing their policy perspective to state organizations (Abraham and Lewis 2000, p. 58), but through the accumulation of privatized state resources. Therefore, Wedel's theory was supported over the corporate domination account. ${ }^{7}$ Nonetheless, the dramatic loss of state capacity, coupled with an increase in drug companies' power, suggested that the resulting imbalance of power between the two

\footnotetext{
${ }^{7}$ We must highlight that the importance of the "revolving door" between the pharmaceutical sector and a drug regulatory agency, especially in the United Kingdom, was to some extent determined by the fact that certain medical specialities, like toxicologists or pathologists, tend to receive training in the industry prior to working for regulatory agencies (cf. Abraham and Lewis 2000). By contrast, the "Fire-Exit" syndrome concerned professions like lawyers or pharmacists, which, by their very nature, did not require a similar period of industry training. However, the "Fire-Exit" syndrome was not determined merely by the professional backgrounds of mobile state officials. Rather, the key underlying dynamics of the mobility pattern that we identified was the massive disproportion between the financial incentives and career opportunities offered by the post-communist state and multinationals. This made it, therefore, a uniquely post-communist phenomenon.
} 
sides was even more extreme under post-communism than in the United States or the United Kingdom.

Finally, it is worth asking a question about the possible durability of the uniquely post-communist "Fire Exit" syndrome. In this respect, we formulate two hypotheses. Unless the state capacity is increased through pouring more financial resources into the state organizations involved in drug reimbursement, we predict that they will continue to train "privatizing" employees for the pharmaceutical sector. On the other hand, creating more competitive working conditions in the state organizations will lead to the emergence of the revolving door familiar from the United States or the United Kingdom. In that case, drug companies will privatize less state resources, but will still be able to transfer their policy perspective to the state organizations.

\section{Conclusion}

We have argued that in the early 2000s the dominant actors in Poland's reimbursement policymaking were multinational corporations collaborating with locally based cliques comprising political elites, bureaucrats, and medical experts. Therefore, our findings were best described by a combination of corporate domination and clique theories, with limited support for neopluralism, and even less for historical institutionalism.

Our data were only partially consistent with the neopluralist position. Patient organizations enjoyed extensive policy access and some of them managed to secure, in collaboration with drug companies, the reimbursement of "niche-buster" medicines. Nevertheless, patient organizations' poor financial and organizational resources, combined with powerful mechanisms of control employed by the industry, were likely to turn patients into pharma's "assimilated allies" (Abraham 2009).

Our data contrasted with the historical institutionalist position. The lack of insulation of the reimbursement process indicated the state's diminished autonomy. Furthermore, the limited expert and bureaucratic capacity suggested a post-communist variant of a "minimalist state" (Abraham and Lewis 2000) in pharmaceutical policy-making. The evidence of pharma's cooptation of key "countervailing powers" (Abraham 2009) state bureaucracy and experts involved in drug evaluation-puts a question mark over the state's ability to make informed decisions concerning complex medical products, often supported by questionable scientific evidence (Abraham and Davis 2009). These challenges in establishing state capacity in drug reimbursement are part of a broader problem of institutional volatility in Poland's healthcare during the less than thirty years after the collapse of the communist system of healthcare provision.

In contrast, corporate domination theory and the post-communist clique theory were strongly supported by our data. The rapid rise in spending on niche-buster medicines demonstrated that pharma and local political elites were benefitting from the current reimbursement regime. Corporate domination theory rightly envisaged the effectiveness of employing patient organizations as third parties in lobbying campaigns, consistent with the "patient-industry complex" model identified in Western countries (Davis and Abraham 2010). The prominence of informal techniques involving the alignment with various domestic cliques, nevertheless, fell outside of the main thrust of corporate domination theory - that corporations exert influence mainly via the formal relationships (e.g., lobbying, campaign contributions, support for policy planning 
networks). Further, we did not find two-way mobility between state bureaucracies and business as in the West, but a one-way mobility pattern in which the state was losing its personnel. Post-communist clique theory, however, can account for these phenomena. The pattern of personal relationships, informal influence, and privatization of state resources involved in drug reimbursement policy fits with the general set of chronic problems in procurement of medical equipment, clinical decision-making, and doctorpatient interactions. In a striking resemblance to our findings concerning the blurring of the private-public divide in drug reimbursement by elite cliques, an EU-led report concluded, "A lack of sensitiveness to a potential conflict of interest is quite characteristic to for the Polish healthcare" (European Commission 2013, p. 287).

An important distinguishing feature of Poland's reimbursement policy, contrasting with Abraham's (2007) “neoliberal corporate bias" model, was pharma's weak sectoral representation and the lack of established, vertically centralized forums for negotiation with the Ministry of Health. Furthermore, pharmaceutical companies and the state did not collaborate in promoting a local innovative pharmaceutical sector (Abraham 2009; Evans 1995). Instead, a partnership was established between multinationals and local cliques appropriating state power in the field of politics and bureaucracy. Additionally, pharma used not only cooptation but also coercion to control other policy actors, particularly some medical experts and patient organizations (Abraham and Davis 2009; Davis and Abraham 2010).

More broadly, our findings suggest that in the early 2000s post-communist cliques operating in the field of drug reimbursement could be viewed as a "comprador class," that is, "indigenous allies" handsomely rewarded for helping multinational drug companies deploy their massive economic resources and transform them into political influence (cf. Poulantzas 1976). On the one hand, cliques were an "invaluable asset" (Wedel 1998, p. 93) to the multinationals, instrumental in accessing and influencing local political elites, experts, and bureaucrats. On the other, enrichment resulting from financial transfers from Western corporations was likely to make those intermediaries less vulnerable to, for example, political changes at the top of the Ministry of Health's political leadership (cf. Wedel 1998, chapter 3; 2009, chapter 3).

It is important to highlight that we have examined the case of a specific policy, with a very strong economic position of multinationals, the sole providers of "innovative" drugs reimbursed by the Polish state. Therefore, the policy influence of multinationals is likely to be less prominent in sectors with remaining strong presence of state-owned (e.g., railway, postal services, coal mining, energy distribution) or state-controlled (e.g., petroleum, copper mining) enterprises, where political elites can still employ powerful mechanisms of control such as appointment of board members (Jarosz 2001) and individual or mass clientelism (Gadowska 2002). Similarly, the emerging domestic grand bourgeoisie may be a counterweight to multinationals in sectors where it has gained a strong position, including leasing, banking, insurance, real estate, software, and the media (Szélenyi 2010). However, any intensive political clash between domestic and foreign capitalists is unlikely, primarily because large domestic enterprises are typically structurally dependent on foreign firms in one way or the other (King 2007), and frequently become subject to takeovers by multinationals (Drelich 2011, p. 22). This is illustrated by military procurement, where major local companies are either subsidiaries of or closely cooperate with multinationals contractors in bidding for contracts from the Ministry of Defense (Lentowicz 2016). 
Nevertheless, we expect that the second element of the power structure we identified, elite cliques, is not unique to drug reimbursement or pharmaceuticals. The operation of cliques is increasingly well documented, including their ability to place key members in top positions in politics, bureaucracy, but also private and state-owned or controlled enterprises, lobbying intermediaries, civil society organizations, and the media (e.g., Wedel 1998, 2009; Zybertowicz 2005). The evidence of clique activity is also consistent with examples of selective informal openness of the policy process (Meyer 2006) and news coverage of informal lobbying involved in the development of regulations in areas as diverse as recycling or personal lending (Makowski 2015).

Beyond Poland, we expect to find similar patterns of reimbursement policymaking elsewhere in Central and Eastern Europe especially in the Visegrad countries (the Czech Republic, Slovakia, Hungary), displaying a similar pattern of deep institutional reform, resource constraints, and widespread informal access mechanisms to rationed health services (European Commission 2013). These countries have displayed varying levels of commitment in importing Western institutions, especially Health Technology Assessment agencies, to their reimbursement systems, with Poland being an undisputed regional leader, followed by Hungary, while the Czech Republic and Slovakia show more resistance to policy diffusion (Gulacsi et al. 2014). Despite the differences in the formal institutional setup, drug reimbursement has been highlighted as a key area of corrupt practices in the Czech Republic, Hungary, and Slovakia (European Commission 2013). Also, locally based informal groups of experts, bureaucrats, and private-sector consultants - similar to the cliques we identified in Poland-played a major role in shaping the reimbursement system in the Czech Republic (Loblova 2016), and informal lobbying and intermediaries are expected to be prominent in all countries of the region (Kaló et al. 2016). Further, the Visegrad counties have experienced similar problems with building state capacity in the field of drug reimbursement, especially in developing and retaining strong cadres of experts and bureaucrats (Gulacsi et al. 2014).

Acknowledgements We would like to thank Rob Baggott, Patrick Berhagen, G. William Domhoff, Grant Jordan, David Lane, Donald Light, Martin Smith, and Iván Szelényi for their insightful comments on earlier drafts of this article. We extend our thanks to the Theory and Society reviewers for their constructive feedback. Separately, we are grateful to Andrzej Zybertowicz for support during the fieldwork, Lukasz Raciborski for conducting 27 interviews, and Robert Socha for providing us with data from a Prosecutor's investigation. Piotr Ozieranski is indebted to the Department of Sociology, University of Cambridge and St Edmund's College for research grants.

Open Access This article is distributed under the terms of the Creative Commons Attribution 4.0 International License (http://creativecommons.org/licenses/by/4.0/), which permits unrestricted use, distribution, and reproduction in any medium, provided you give appropriate credit to the original author(s) and the source, provide a link to the Creative Commons license, and indicate if changes were made.

\section{References}

Abraham, J. (2002). Transnational industrial power, the Medical profession and the regulatory state: Adverse drug reactions and the crisis over the safety of halcion in the Netherlands and the UK. Social Science \& Medicine, 55(9), 1671-1690.

Abraham, J. (2007). From evidence to theory: Neo-liberal corporate bias as a framework for understanding UK pharmaceuticals regulation - Response to Alison Edgely. Social Theory \& Health, 5, 161-175. 
Abraham, J. (2009). Partial progress: Governing the pharmaceutical industry and the NHS, 1948-2008. Journal of Health Politics, Policy and Law, 34(6), 931-977.

Abraham, J. (2010a). On the prohibition of conflicts of interest in pharmaceutical regulation: Precautionary limits and permissive challenges. A Commentary on Sismondo $(66: 9,2008,1909-14)$ and O'Donovan and Lexchin. Social Science \& Medicine, 70, 648-651.

Abraham, J. (2010b). Pharmaceuticalization of society in context: Theoretical, empirical and health dimensions. Sociology, 44(4), 603-622.

Abraham, J., \& Davis, C. (2009). Drug evaluation and the permissive principle: Continuities and contradictions between standards and practices in antidepressant regulation. Social Studies of Science, 39(4), 569598.

Abraham, J., \& Lewis, G. (2000). Regulating medicines in Europe: Competition, expertise and public health. London: Routledge.

AHTAPol. (2007). Guidelines for conducting health technology assessment. Krakow-Warszawa. http://www. archiwum.aotm.gov.pl/pliki/edu/Wytyczne\%20HTA\%20w\%20AOTM_EN.pdf (accessed March 15, 2012).

AHTAPol . (2009). Guidelines for conducting health technology assessment. Warsaw. http:/www.aotm.gov. pl/assets/files/wytyczne_hta/2009/09.06.29_wytyczne_HTA_eng_MS.pdf (accessed March 15, 2012).

AHTAPol . (2011). Regulamin Rady Konsultacyjnej Agencji Oceny Technologii Medycznych. http://aotm.gov. pl/assets/files/rada/regulamin-29-03-2011/Regulamin_RK_AOTM_29032011.pdf (accessed November 23, 2011).

AHTAPol . (2012). Wytyczne HTA. http://www.aotm.gov.pl/index.php?id=13 (accessed March 29, 2012).

Anderson, R. (2014). Pharmaceutical industry gets high on fat profits. BBC News, November 6. http://www. bbc.co.uk/news/business-28212223 (accessed July 26, 2016).

Angell, M. (2005). The truth about drug companies. How they deceive us and what to do about it? New York: Random House.

Baggott, R., Allsop, J., \& Jones, K. (2005). Speaking for patients and carers. Health consumer groups and the policy process. Basingstoke: Palgrave.

Baumgartner, F. R., Berry, J. M., Hojnacki, M., Kimball, D. C., \& Leech, B. M. (2009). Lobbying and policy change. Who wins, who loses, and why. Chicago: The University of Chicago Press.

Bourdieu, P. (1994). Rethinking the state: Genesis and structure of the bureaucratic field. Sociological Theory, $12(1), 1-18$.

Charmaz, K. (2006). Constructing grounded theory. A practical guide through qualitative analysis. London: Sage Publications.

Cichosz, M. (2001). Zaklęte rwiry prywatyzacji. In M. Jarosz (Ed.), Manowce polskiej prywatyzacji. Studia pod redakcja Marii Jarosz (pp. 72-90). Warszawa: Wydawnictwo Naukowe PWN, Instytut Studiów Politycznych PAN.

Conrad, P. (2007). The Medicalization of society: On the transformation of human conditions into treatable disorders. Baltimore, Maryland: Johns Hopkins University Press.

Czapiński, J., \& Panek, T. (Eds.). (2007). Diagnoza społeczna 2007. Warunki i jakość życia Polaków. Warszawa: Rada Monitoringu Społecznego.

Daemmrich, A. (2004). Pharmacopolitics. Chapel Hill: University of North Carolina Press.

Davis, C., \& Abraham, J. (2010). Rethinking innovation accounting in pharmaceutical regulation. Science, Technology \& Human Values: Official Journal of the Society for Social Studies of Science, 36(6), 1-25.

Davis, C., \& Abraham, J. (2011a). Desperately seeking cancer drugs. Sociology of Health and Illness, 33(5), 731-747.

Davis, C., \& Abraham, J. (2011b). The socio-political Roots of pharmaceutical uncertainty. Social Science \& Medicine, 72, 1574-1581.

Devictor, X. (2012). Poland: Aging and the economy. World Bank News. http://www.worldbank. org/en/news/opinion/2012/06/14/poland-aging-and-the-economy (accessed April 22, 2013).

Dolgin, E. (2010). Big pharma moves from 'blockbusters' to 'niche busters. Nature Medicine, 16(8), 837.

Domhoff, G. W. (2006). Who rules America? Power, politics \& social change. Boston: McGraw-Hill.

Domhoff, G. W. (2009). The power elite and their challengers: The role of nonprofits in American social conflict. American Behavioral Scientist, 52(7), 955-973.

Domhoff, G. W., \& Webber, M. J. (2011). Class and power in the New Deal. Corporate moderates, Southern democrats and the liberal-labor coalition. Stanford: Standford University Press.

Drelich, K. (2011). Fuzje i przejęcia w latach 2007-2009. Polska na tle tendencji globalnych. Kraków: Instytut Rozwoju Przedsiębiorstw Marcin Nytko.

Ekiert, G., \& Kubik, J. (2001). Rebellious civil society: Popular protest and democratic consolidation in Poland, 1989-1993. Ann Arbor: University of Michigan Press. 
Emerson, R. M. (2001). Producing Ethnographies. Theory, Evidence and Representation. In R. M. Emerson (Ed.), Contemporary Field Research. Perspectives and Formulations (pp. 281-316). Long Grove: Waveland Press.

European Commission. (2004). Useful information on rare diseases from an EU perspective. Health \& Consumer Protection Directorate General.

European Commission. (2013). Study on corruption in the healthcare sector. HOME/2011/ISEC/PR/047-A2. http://ec.europa.eu/dgs/home-affairs/what-is-new/news/news/docs/20131219_study_on_corruption_in_ the_healthcare_sector_en.pdf (Accessed July 20, 2016).

Evans, $\bar{P}$. (1995). Embedded autonomy. States and industrial transformation. Princeton: Princeton University. Eyal, G., Szelényi, I., \& Townsley, E. (1998). Making capitalism without capitalists: The new ruling elites in Eastern Europe. London: Verso.

Finegold, K., \& Skocpol, T. (1995). State and party in America's New Deal. Madison: University of Wisconsin Press.

Fishman, J. (2004). Manufacturing desire: The commodification of female sexual dysfunction. Social Studies of Science, 34, 187-218.

Forbes. (2015). Wydajemy miliony na lekarstwa. Rynek farmaceutyczny rośnie w siłe. July 3. http://www. forbes.pl/wydajemy-miliardy-na-lekarstwa-rynek-farmaceutyczny-rosnie-w-sile, artykuly,196761,1,1.html (accessed July 26, 2016).

Gadowska, K. (2002). Zjawisko klientelizmu polityczno-ekonomicznego. Systemowa analiza powiazań sieciowych na przykładzie przekształceń sektora górniczego w Polsce. Kraków: Wydawnictwo Uniwersytetu Jagiellońskiego.

Geertz, C. (1973). Thick description: Toward an interpretive theory of culture. In The Interpretation of Cultures: Selected Essays (pp. 3-30). New York: Basic Books.

Golinowska, S. (Ed.). (2008). Finansowanie ochrony zdrowia w Polsce. Zielona Ksiegga II. Warszawa.

Grzymała-Busse, A. (2007). Rebuilding the Leviathan: Party competition and state exploitation in postcommunist democracies. Cambridge: Cambridge University Press.

Gulácsi, L., Rotar, A. M., Niewiada, M., Löblová, O., Rencz, F., Petrova, G., Boncz, I., \& Klazinga, N. S. (2014). Health technology assessment in Poland, the Czech Republic, Hungary, Romania and Bulgaria. The European Journal of Health Economics, 15, 13-25.

GUS. (2011). Informacja o rozmiarach i kierunkach emigracji z Polski w latach 2004-2010. Warszawa: Glowny Urzad Statystyczny.

Hausner, J., \& Marody, M. (Eds.). (2000). Jakość rzadzenia: Polska bliżej Unii Europejskiej? Kraków: Małopolska Szkoła Administracji Publicznej Akademii Ekonomicznej w Krakowie.

Healey, D. (2004). Shaping the intimate: Influences of the experience of everyday nerves. Social Studies of Science, 34(2), 219-245.

Health Committee. (2005). The influence of the pharmaceutical industry. Fourth report of session 2004-2005. London: Stationery Office.

Hemminki, E., Toiviainen, H. K., \& Vuorenkoski, L. (2010). Co-operation between patient organisations and the drug industry in Finland. Social Science and Medicine, 70(8), 1171-1175.

Higley, J., \& Lengyel, G. (2000). Elites after state socialism: Theories and analysis. Oxford: Rowman and Littlefield.

HiT. (2011). Poland: Health system review. Health Systems in Transition, 13(8), 1-193.

Hood, C. (2011). The blame game: Spin, bureaucracy and self-preservation in government. Princeton: Princeton University Press.

Jarosz, M. (2001). Rady nadzorcze w kleszczach interesów partyjnych i grupowych. In M. Jarosz (Ed.), Manowce polskiej prywatyzacji. Studia pod redakcja Marii Jarosz (pp. 44-71). Warszawa: Wydawnictwo Naukowe PWN, Instytut Studiów Politycznych PAN.

Jasiecki, K. (2013). Kapitalizm po polsku. Miedzy modernizacja a peryferiami Unii Europejskiej. Warszawa: Wydawnictwo IFiS PAN.

Kaló, Z., Gheorghe, A., Huic, M., Csanádi, M., \& Kristensen, F. B. (2016). HTA implementation roadmap in Central and Eastern European Countries. Health Economics, 25, 179-192.

King, L. (2007). Central European capitalism in comparative perspective. In R. Hanké, M. Thatcher, \& M. Rhodes (Eds.), Beyond Varieties of Capitalism (pp. 307-327). Oxford: Oxford University Press.

King, L., \& Szelényi, I. (2005). Post-communist economic systems. In N. Smelser \& R. Swedberg (Eds.), The Handbook of Economic Sociology (pp. 206-232). Princeton: Princeton University Press.

King, L., \& Sznajder, A. (2006). The state-led transition to liberal capitalism: Neoliberal, organizational, world-systems, and social structural explanations of Poland's economic success. American Journal of Sociology, 112(3), 751-801.

Kornai, J. (1980). Economics of Shortage. Amsterdam: North-Holland. 
Lakoff, A. (2004). The anxieties of globalisation: Antidepressant sales and economic crisis in Argentina. Social Studies of Science, 34, 247-269.

Ledeneva, A. (2006). How Russia really works? The Informal practices that shaped post-soviet politics and business. Ithaca: Cornell University Press.

Lentowicz, Z. (2016). Polski przemysł zbrojeniowy potrzebuje jasno określonej przemysłowo-obronnej strategii. Rzeczpospolita, January 27. http://www.rp.pl/Biznes/301279908-Polski-przemysl-zbrojeniowypotrzebuje-jasno-okreslonej-przemyslowo-obronnej-strategii.html\#ap-2 (accessed July 27, 2016).

Lexchin, J. (2006). The pharmaceutical industry and the pursuit of profit. In J. C. Cohen (Ed.), The Power of Pills: Social, Ethical and Legal Issues in Drug Development, Marketing and Pricing (pp. 1-24). London: Pluto Press.

Lexchin, J., \& O'Donovan, O. (2010). Prohibiting or 'managing' conflict of interest? A review of policies and procedures in three European drug regulation agencies. Social Science \& Medicine, 70, 643-647.

Light, D. (1995). Countervailing powers: A framework for the professions in transition. In T. Johnson, G. Larkin, \& M. Saks (Eds.), Health Professions and the State in Europe (pp. 23-43). London: Routledge.

Loblova, O. (2016). (2016). Halted diffusion: Epistemic communities and the non-adoption of health technology assessment agencies in Central and Eastern Europe. Unpublished $\mathrm{PhD}$ dissertation. Central European University: Budapest.

Makowski, G. (2015). Czy możliwy jest przejrzysty lobbing? Raport o potrzebie lepszych regulacji i dobrych praktyk działalności lobbingowej. Warszawa: Fundacja im. Stefana Batorego.

Meyer, G. (Ed.). (2006). Formal Institutions and Informal Politics in Central and Eastern Europe. Hungary, Poland, Russia and Ukraine. Opladen and Farmington Hills: Barbara Budrich Publishers.

Ministerstwo Zdrowia. (2011). Rejestr korzysci. http://www.mz.gov.pl/wwwfiles/ma struktura/docs/rejestr korzysci 17112011.pdf (accessed December 10, 2011).

McFarland, A. (2004). Neopluralism: The evolution of political process theory. Lawrence, KS: University Press of Kansas.

NFZ. (2005). Analiza wydatków Narodowego Funduszu Zdrowia z tytulu refundacji leków w roku 2004 (p. 2005). Warszawa: Narodowy Fundusz Zdrowia, Zespół Gospodarki Lekami.

NFZ. 2006a. Sprawozdanie z działalności Narodowego Funduszu Zdrowia za 2005 rok. Warszawa.

NFZ. (2006b). Wydatki Narodowego Funduszu Zdrowia z tytułu refundacji leków w roku 2005. Warszawa: Narodowy Fundusz Zdrowia, Departament Gospodarki Lekami.

NFZ. (2007). Sprawozdanie z działalności Narodowego Funduszu Zdrowia za 2006 rok. Warszawa: Narodowy Fundusz Zdrowia.

NFZ. (2008). Sprawozdanie z działalności Narodowego Funduszu Zdrowia za 2007 rok. Warszawa.

NFZ. (2009). Sprawozdanie z działalności Narodowego Funduszu Zdrowia za 2008 rok. Warszawa.

NFZ. (2010). Sprawozdanie z działalności Narodowego Funduszu Zdrowia za 2009 rok. Warszawa.

NFZ. (2011). Sprawozdanie z działalności Narodowego Funduszu Zdrowia za 2010 rok. Warszawa.

NIK. (2004). Informacja o wynikach kontroli funkcjonowania systemu tworzenia wykazu leków refundowanych. KPZ-41105-2003.

NIK. (2007). Wystapienie pokontrolne. Samodzielny Publicznym Szpitalu Klinicznym nr 5 Ślaskiego Uniwersytetu Medycznego. K-08-016-LKA-01-01.

NIK. (2010a). Informacja o wynikach kontroli realizacji zakupów sprzętu medycznego i leków przez szpitale kliniczne oraz finansowania przez dostawców różnych sfer działalności tych szpitali, $w$ tym dotyczacych badań klinicznych. LKA-41043-08.

NIK. (2010b). Wystapienie pokontrolne. Zespół Opieki Zdrowotnej w Końskich (ZOZ). LKI-4112-01/2009.

Niżankowski, R., \& Wilk, N. (2009). From idealistic rookies to a regional leader: The history of health technology assessment in Poland. International Journal of Technology Assessment in Health Care, 25, $156-162$.

OECD. (2014). Pharmaceutical expenditure per capita at current prices and PPPs: 2006-2013. http://www. oecd-ilibrary.org/social-issues-migration-health/pharmaceutical-expenditure-per-capita_pharmexpcaptable-en.

Ozieranski, P., McKee, M., \& King, L. (2012a). Pharmaceutical lobbying under postcommunism: Universal or country-specific methods of securing state drug reimbursement in Poland? Health Economics, Policy and Law, 7(2), 175-195.

Ozieranski, P., McKee, M., \& King, L. (2012b). The politics of health technology assessment in Poland. Health Policy, 108(2-3), 178-193.

Piecha, B. (2006). Remark made during the $31^{\text {st }}$ session of the Senate of the Republic of Poland. http://www. senat.gov.pl/k6/dok/sten/031/12.HTM (accessed September 26, 2010).

Podgórecki, A. (1994). Polish society. Westport and London: Praeger.

Poulantzas, N. (1976). The crisis of the dictatorships. London: New Left Books. 
Prokuratura Apelacyjna. (2010). Postanowienie o umorzeniu sledztwa. Krakow: Sygn. Akt Ap. V Ds. 20/09/S. Rada Ministrów. (2010). Uzasadnienie projektu ustawy o refundacji leków, środków spożywczych specjalnego przeznaczenia żywieniowego oraz wyrobów medycznych przyjęty przez rząd 14 października $2010 \mathrm{r}$.

Rampton, S., \& Stauber, J. C. (2001). Trust us, we're experts! How industry manipulates science and gambles with your future. New York: Jeremy P. Tarcher/Putnam.

Staniszkis, J. (1999). Post-communism - The emerging Enigma. Warsaw: Institute of Political Studies, Polish Academy of Sciences.

Staniszkis, J. (2003). Władza globalizacji. Warsaw: Wydawnictwo Naukowe Scholar.

Sygut, M. (2012). Korupcja zaczyna się od omijania kolejek. Rynek Zdrowia. June 16. http://www. rynekzdrowia.pl/Prawo/Korupcja-zaczyna-sie-od-omijania-kolejek,120394,2.html (accessed June 25, 2016).

Szelényi, I. (2010). The new grand bourgeoisie under post-communism. Central Europe, Russia nad China compared. Working Paper NO. 2010/63, United Nations University, World Institute for Developent Economic Research.

Ustawa. (2009). Ustawa o świadczeniach opieki zdrowotnej finansowanych ze środków publicznych z dnia 27 sierpnia 2004 r. Dz.U. 2004 Nr 210 poz. 2135 z pozn. zm.

Vogler, S., Habl C., Leopold C., Rosian-Schikuta, I.., de Joncheere K., \& Thomsen T. L. (2008). PPRI Report. Vienna. http://ppri.oebig.at/Downloads/Publications/PPRI_Report_final.pdf (accessed October 10, 2010).

Wedel, J. (1986). The private Poland. New York and Oxford: Facts on File Publications.

Wedel, J. (1998). Collision and collusion. The strange case of Western aid to Eastern Europe 1989-1998. New York: St. Martin's Press.

Wedel, J. (2009). Shadow elite. How the world's new power brokers undermine democracy, government, and the free market. New York: Basic Books.

Vuorenkoski, L., Toiviainen, H., \& Hemminki, E. (2003). Drug reimbursement in Finland: A case of explicit prioritising in special categories. Health Policy, 66(2), 169-177.

Wyżnikiewicz, B. (2009). Znaczenie sektora farmaceutycznego dla gospodarki polskiej. Warszawa: Instytut Badań nad Gospodarką Rynkową.

Zybertowicz, A. (2005). Anti-developmental interest groups (preliminary outline). Polish Sociological Review, 149(1), 69-90.

Piotr Ozieranski is Lecturer in the Department of Social and Policy Sciences, University of Bath, UK. His research interests are in medical and political sociology, with a particular emphasis on pharmaceutical regulation, drug pricing and reimbursement, and health technology assessment. He investigates these issues using mixed-method research designs, drawing, amongst others, on documentary sources and interviews. His articles have been published in various sociology, health policy, and applied healthcare research journals.

Lawrence King is Professor of Economics in the Department of Economics, University of Massachusetts, Amherst, USA. His longstanding areas of interest include political economy of post-communism and of public health, including a large-scale multi-method study of the mortality crisis in the former Eastern Bloc. Most recently he has been developing a research agenda focusing on the financialization of the pharmaceutical sector, including case studies of highly expensive breakthrough drugs for hepatitis C. His work has been published in leading sociology, public health, and medical journals. Appendices for this article can be found on King's website: http://www.lawrenceking.net 